\title{
UNA DE CAL Y OTRA DE ARENA: BUILDING COMPARABLE REAL WAGES IN A GLOBAL PERSPECTIVE*
}

\author{
ROBERT C. ALLEN \\ New York University ${ }^{\mathrm{a}}$ \\ TOMMY E. MURPHY \\ Università Bocconi ${ }^{\mathrm{b}}$ \\ ERIC B. SCHNEIDER \\ University of Sussex ${ }^{\mathrm{c}}$
}

\begin{abstract}
This paper discusses some of the criticisms recently raised by Rafael Dobado-González about our work on real wages in the Americas in the long run. Although addressing a series of issues, Dobado mainly questions our use of the welfare ratio methodology to assess standards of living in colonial Spanish America. In this article we explain how, despite its limitations, this methodology provides a solid, transparent metric to compare economic development across space and time. In particular, welfare ratios present more economically relevant information on living standards than the commodity wages that Dobado prefers (Dobado González and García Montero 2014). We argue that Dobado fails to offer convincing evidence against our findings; hence, we stand by these results, which suggest that the divergence between North and Latin America began early in the colonial period.
\end{abstract}

Keywords: economic history, real wages, standard of living, Great Divergence, Latin America

JEL Code: N16, N36, I32

* Received 21 December 2014. Accepted 5 January 2015.

a Social Science Faculty A5 169, P.O. Box 129188, Abu Dhabi, United Arab Emirates. bob.allen@nyu.edu

b Department of Policy Analysis and Public Management (PAM) and Dondena Centre for Research on Social Dynamics and Public Policy, Università Commericiale Luigi Bocconi, Via Röntgen 1, 20136 Milano, Italy. tommy.murphy@unibocconi.it

c Department of History, University of Sussex, Arts Road, Falmer, Brighton, BN1 9QN, United Kingdom. e.b.schneider@sussex.ac.uk 


\section{RESUMEN}

Este artículo discute algunas de las recientes críticas de Rafael DobadoGonzález (2015) a nuestro trabajo sobre la evolución de los salarios reales en el continente americano en el largo plazo (Allen et al. 2012). Aunque discutiendo una serie de puntos, Dobado hace particular hincapié en la validez del uso de la metodología de ratios de bienestar (welfare ratios) para evaluar niveles de vida en la Hispanoamérica colonial. En el presente trabajo explicamos cómo, a pesar de sus limitaciones, esta metodología provee una métrica sólida y transparente para comparar desarrollo económico, tanto a través del espacio, como a través del tiempo. En particular, exponemos cómo los ratios de bienestar presentan información económicamente más relevante sobre éstos niveles de vida que los salarios en términos de commodities que Dobado prefiere (Dobado González and García Montero 2014). En suma, proponemos que Dobado no proporciona argumentos convincentes en contra de nuestros resultados, que sugieren que la divergencia entre América del Norte y América Latina comenzó temprano en el periodo colonial, por lo que consideramos que esa lectura de la evidencia sigue siendo válida.

Palabras clave: historia económica, salarios reales, niveles de vida, Gran Divergencia, América Latina

\section{INTRODUCTION}

Real wages are one of the most versatile instruments in the economic historian's toolkit. Although they have limitations, ratios of nominal wages to the cost of a basket of goods provide a transparent way to gauge standards of living and how they vary across time and space. By using a clear theoretical framework, they allow us to make sense of the sometimes-scant data available to study the human past, hence providing — as the well-known Spanish saying states - «una de cal y otra de arena» (one [measure] of quicklime and another of sand): a solid foundation resulting from the combination of two very different, weaker elements on their own.

\section{REAL WAGES IN THE GREAT DIVERGENCE DEBATE}

There is an enduring interest among historians and economists as to why some countries are rich and others poor. This interest has manifested in different ways over the years. Within economic history, research of a half a century ago typically framed the question in terms of specific case studies, 
such as why England had an Industrial Revolution instead of France (e.g. Hartwell 1967), or what explains the long-term decline of Imperial Spain (e.g. Elliott 1963). In the last few decades, however, this enquiry has taken on a global dimension, and increasingly poses the question of why Europe pulled ahead of the rest of the world (e.g. North and Thomas 1973; Jones 1981; Bairoch 1988; Diamond 1998; Landes 1998; Allen 2009). The Great Divergence debate (Pomeranz 2000), trying to explain how and why Western Europe escaped from centuries of stagnation leaving other parts of the world behind, is undoubtedly one of the liveliest in the discipline these days.

A crucial upshot of this debate has been a renewed interest in assessing exactly how well different regions performed in terms of income in the long run. Because the most natural measure to use, the gross domestic product (GDP), faces serious limitations for historical studies due to the heavy demand on very detailed data, and work on other types of information such as anthropometric measures is still evolving (Salvatore et al. 2010; Dobado González and García Montero 2014), various scholars advocate the construction and use of real wages indexes (e.g. van Zanden 1999; Allen 2001).

Real wages are particularly appealing for the study of income in the past in at least three senses. First, they provide an intuitive way of looking at standards of living, very much related to the now widely known concept of the poverty line (Allen 2013), as used in the World Bank's «wretched dollar» now familiar in the development literature (e.g. Deaton 2006). The fundamental idea is that a person who earns a living spends his/her salary on a certain number of basic goods such as food, clothing or fuel, and his/her welfare depends on how many of those goods he/she can purchase. If one has information on wages and the prices of a basket of goods typically available in that place, one can get an idea of whether that income is enough for basic subsistence by calculating the ratio between the wage and the cost of that hypothetical basket. Second, given that the main inputs to estimate this ratio are nominal wages and prices, data availability is less of a problem than with the GDP. Prices of goods and labour appearing in the accounting books of long-lasting institutions like hospitals, churches or universities are arguably the oldest continuous objective economic data in existence, and because little could be gained from the destruction of such documents, many survived wars and political upheavals (Hamilton 1944). Lastly, the construction of real wage estimates can incorporate many local subtleties. The definition of the basket, for instance, can integrate information on eating habits, caloric needs associated with typical work performed in the region, or clothing and housing needs or customs. In this way real wages end up being a truly comparative quantitative measure that incorporates qualitative information.

The Great Divergence debate has profited from this approach by showing how the standard of living diverged within Europe (van Zanden 1999; Allen 2001), Northern Europe - especially London — pulling ahead somewhere in the $18^{\text {th }}$ century, and how the rest of the world seems to have followed a 
similar pattern of the worst performers in Europe, contributing to the discussion of why those patterns came to be (e.g. Clark 2008, Allen 2009; van Zanden 2009; Parthasarathi 2011). Although this research on standards of living has indeed been framed as global in emphasis and scope, most work focuses on selected Eurasian cities (e.g. Broadberry and Gupta 2006; Pamuk, 2007; Allen et al. 2011a). The most prominent omission in this literature was certainly that of the New World. It is clear now that by the late $19^{\text {th }}$ century the North American economy had overtaken Europe in income and productivity (Broadberry 1997), and that Latin America was already lagging behind both of them (Edwards et al. 2007), yet we know little about when, how, and why this happened. The contrasting experiences of North and South America, for example, have been particularly puzzling. Both regions had many commonalities, including an abundance of land and natural resources, and openness to immigration and capital imports. Yet they still had very different trajectories of development (Engerman and Sokoloff 1997, 2002), which we could understand better if we knew when and how incomes diverged between the north and the south and between the Americas and Europe (Prados de la Escosura 2007). Also, many participants in the Great Divergence debate believe that the creation of the Atlantic economy and the establishment of European colonies in the Americas in the seventeenth and eighteenth centuries played an important role in explaining the success of Great Britain (e.g. Pomeranz 2000; Acemoglu et al. 2005). However, Spain and Portugal also had American colonial empires and yet fell dramatically behind.

It is this omission that our recent paper in the Journal of Economic History (Allen et al. 2012) tried to fill. There we provide one of the first systematic approaches to study the standards of living in the Americas as measured using the now familiar "welfare ratios». Welfare ratios are real wage estimates built using a basic subsistence (barebones) basket for a small family; hence, a value of one indicates that such a family achieves just subsistence (equivalent to the World Bank poverty line of one dollar per day) and values higher than that allow either sustaining a larger family or consuming more (or better) goods. We then collected information from various secondary sources on prices and nominal wages since colonisation for six cities/regions

\footnotetext{
1 It was quite clear even from the first line of the abstract of that article that with it we did not intend to add to the interesting discussion on anthropometric standards of livings (as in Salvatore et al. 2010), nor to follow the traditional approach of using single commodity ratios (as in Dobado González and García Montero 2009), but to join the growing debate based upon welfare ratios. It was equally explicit that we wanted to do so for cities all over the continent, not only in Spanish America (as in Arroyo Abad et al. 2012). The failure to see this rather explicit feature has prompted Dobado to mistakenly state that in our working paper (Allen et al. 2011b) we "wrongly claimed that "this paper takes a first look at standards of living in a series of North American and Latin American cities » (Dobado-González 2015, footnote 12, Dobado's emphasis). To our knowledge, our working paper, and eventual final publication (Allen et al. 2012), is the first paper to look at North and Latin American standards of living in the long run using welfare ratios.
} 
in the continent (Boston, Philadelphia, the Maryland area, Mexico, Bogota and Potosi) and with these data we constructed welfare ratio series for unskilled free workers for each place. Our results suggested that standards of living diverged in the Americas quite early following European colonisation, the Northern colonies achieving levels comparable to (and even surpassing) those of the top performers in Europe. Spanish America, on the other hand, fared not too different from other parts of the world and, in particular, the evidence available on Spain. These findings led us to hypothesise that there was probably some level of integration between the European powers and their colonies.

\section{NOT POOR, NOR SHORT}

Dobado is an optimist, and thinks that those results are seriously misleading ${ }^{2}$. According to him, the inhabitants of colonial Spanish Latin America did very well, as living standards were not far behind the rest of the world. His reading of the evidence on wages and prices is that workers in Mexico, Bolivia and Argentina were as well off as (or even better than) those in leading European countries in the seventeenth and eighteenth centuries. This seems to be reinforced by information on heights, as the data he surveys suggest that Spanish American were taller than many Europeans. This interpretation leads Dobado to cast doubts on "pessimistic» narratives (Engerman and Sokoloff 1997, 2002; Acemoglu et al. 2001, 2002) that emphasise the negative impact of the colonial status on the region. At the core of Dobado's argument is the idea that reconstructing price baskets for historical periods is a deeply flawed methodology, so we can better compare international performances combining information from wages based on one commodity (silver, grain, meat and sugar wages) and anthropometric information, what Dobado refers to as the Dobado-García approach (Dobado González and García Montero 2014) ${ }^{3}$.

2 Unless otherwise specified, we refer to Dobado's interpretation according to his article published in RHE-JILAEH (Dobado-González 2015), although many of his arguments in that article follow closely those of his other contributions, especially along García (e.g. Dobado González and García Montero 2014). Also, many of Dobado's points really have to do with our working paper (Allen et al. 2011b) and not our actual publication (Allen et al. 2012). Since some of the issues he raises refer to elements that were already addressed in the final publication, which now has been out for nearly 2 years, save for some occasional clarification we are not going to delve into them.

3 Dobado also raised some additional minor concerns regarding our interpretation of our actual findings. For example, he found hard to believe the existence of two separate, integrated labour markets across the Atlantic (one of Britain and its colonies, and another of Spain and Spanish America). On this he could be right, but he does not provide enough evidence to make a solid case for it. His main argument is that immigration to Spanish America was not large enough to allow this integration (Dobado-González 2015, p. 25). Yet that migration was not as low as one might expect and included migrants from a wide range of society, as we pointed out in our paper (Allen et al. 2012, p. 881). Further, large immigration figures are not a necessary condition for labour market 


\section{SEARCHING FOR THE BEST REAL WAGE COMPARISON}

Much of Dobado's argument circles around the idea that estimating welfare ratios has too many flaws and we are better off sticking to single goods ratios or, to follow the quicklime and sand analogy used earlier, we are better of going back to mud. We do not share this view. Some issues are contentious, but we believe many of the points he raises are indeed valid and need to be discussed extensively if we want to construct measures that allow us to improve our understanding of how standards of living evolved in a global perspective. But, in any case, we certainly fail to see how most of those criticisms can imply the so-called Dobado-García approach provides a better alternative.

Although it has been done elsewhere, it is probably useful at this stage to make clear and explicit what the methodology we are using does. Comparisons of cost of living have been taking place always (van Zanden 1999), but the publication of the paper by Allen (2001) marks the time in which the discussion took a new direction. The proposal there was to present the information in terms of welfare ratios that have a very specific meaning. The basic idea is incorporated in this relationship:

$$
\text { Real wage }=\frac{w_{t} \times d_{t}}{b_{t} \times h_{t}+r_{t}}
$$

Here $w_{t}$ is the daily wage and $d_{t}$ the amount of days worked in a year, so the numerator indicates the total nominal yearly income of the labourer. The denominator is of course supposed to reflect somehow the purchasing power of that income, so it incorporates the cost of a basic basket of goods $\left(b_{t}\right)$ scaled by the household size $\left(h_{t}\right)$ and the cost of lodging $\left(r_{t}\right)$. The cost of the basket is determined by the product of two vectors, one of prices and one of quantities:

$$
b_{t}=\mathbf{p}_{t}^{\prime} \times \mathbf{q}_{t}
$$

Where each vector is composed of a series of elements, typically corresponding to food and non-food products:

$$
\mathbf{p}_{t}=\left(\begin{array}{l}
\mathbf{p}_{t}^{\mathrm{nf}} \\
\mathbf{p}_{t}^{\mathrm{nf}}
\end{array}\right) \quad \mathbf{q}_{t}=\left(\begin{array}{c}
\mathbf{q}_{t}^{\mathrm{nf}} \\
\mathbf{q}_{t}^{\mathrm{nf}}
\end{array}\right)
$$

It follows directly from this brief description that each individual element is crucial to interpret the welfare ratio (1), and even if reliable sources existed for all of them, the researcher will always have to exercise a certain level of discretion. This is particularly the case for the vector $\mathbf{q}_{t}$. Which basket should we

\footnotetext{
(footnote continued)

integration, as factor price equalisation could also come partly from goods market integration. In any case, these are indeed more contentious issues and, we believe, still open to discussion. Since we do not want to divert attention from Dobado's criticisms of the welfare ratio methodology, which we consider of great importance for the debate on global standards of living, the focus of this article will be entirely on these methodological issues.
} 
select? The one typically purchased by the worker being paid $w_{t}$ ? «Typical» as in mean or in mode? But perhaps the typical is not as informative as the cheapest, as the latter will really give us a sense of the limitations of the salary. If this is the case, the cheapest basket will probably still require certain minimum amounts of some goods. How to define those? Similar problems are faced with the other components of the relationship, and this is important because by construction - the choice of $w_{t}, d_{t}, r_{t}, h_{t}, \mathbf{p}_{t}$, or $\mathbf{q}_{t}$ will determine the ranking among ratios corresponding to different periods or places. Dearth of data only makes the exercise more complicated, forcing the researcher to make different assumptions along the way, so those real wages are comparable across time and space. It is important to note that any choice will lead to some sort bias, yet estimations can be more or less comprehensive, more or less transparent, and hence, more or less comparable.

With this basic framework in mind, one can see clearly the main critiques to our approach suggested by Dobado-González (2015):

\section{i. The vector $\mathbf{q}_{t}$ is unsuitable because}

a. It is fixed across space: "Allen et al. (2012) rely on an arguable premise: the identity of consumption pattern across the world» (p. 37).

b. It is incomplete, as it does not include all the relevant elements, such as those coming from the Columbian exchange (pp. 38-39).

c. It is fixed across time: "the very notion of an immutable consumption basket during the whole viceregal period conflicts with substantial evidence» (p. 40).

ii. All the other numbers in the relationship are also problematic because they are fixed across time and space:

a. The working days, $d_{t}$ : «A universal estimate of yearly working days is not consistent with the variety of labor practices existing in different economic sectors (...) and their likely long-term change» (p. 40).

b. The household size, $h_{t}$ : «It seems reasonable to expect that the number of family members changed in response to economic conditions and evolved over its life cycle» (p. 41).

c. The cost of rent, $r_{t}$ : «The across the board 5-per cent allowance for rent might also be misleading, since, presumably, it penalizes rural living standard and less dynamic towns over the Early Modern Era» (p. 42).

iii. It is very hard to get a series of vectors $\mathbf{p}_{t}$ : «Far from minor is the problem that Allen's methodology is very data demanding» (p. 43). 
Having accepted these criticisms, Dobado argues that we should revert to the earlier method of calculating wages relative to the prices of specific goods. We find this argument to be seriously flawed for a number of reasons, especially because the empirical strategy he proposes entirely ignores his own criticisms (i) and (ii), and only really deals with (or dodges) problem (iii) above. But rather than providing a litany of counterpoints to Dobado's critique above, we would like to focus our discussion on the benefits of constructing baskets of prices when comparing wages across countries.

Until relatively recently, basically because many scholars agreed with criticism (iii) above, most of the comparisons in terms of standards of living were done using single product comparisons, typically expressing the amount of wheat or other grains that could be purchased with an annual salary (van Zanden 1999). Scholars constructed grain wages because grain prices were readily available and represented one of the most uniform products that could be compared. However, several steps of scholars have moved away from this methodology. First, Phelps-Brown and Hopkins (1981) calculated multi-product cost of living indices to measure real wage trends in various European cities over time. Later, Allen (2001) proposed a standardised basket and calculated real wages that were comparable across space as well as over time. In this way, real wages provided a more realistic and meaningful measure of living standards and economic performance than the earlier grain wages. In addition, Allen's methodology had a clear and explicit set of assumptions, which allowed for the creation of internationally comparable measures.

Of the many theoretical baskets available, the literature has slowly converged to using a «barebones» or subsistence basket (Allen et al. 2011a). This is the "cost of basic subsistence», the minimum resources needed for survival in terms of caloric and protein intake. Barebones baskets include a limited variety of goods, typically a cheap source of calories (normally carbohydrates in the form of grains), some source of protein (legumes and meat), and oil or butter, plus some basic goods for heating (fuel), lighting (candles and lamp oil), clothing (linen or cotton) and hygiene (soap). This basket does not represent what the typical worker consumed (in Europe or otherwise) but instead an essential set of goods from which he or she could survive. It is then a theoretical basket, anchored in empirical evidence, yet based upon basic biological needs. Since it is not strict on the actual goods, but on what those goods provide (e.g. calories and proteins for food products), the basket is geographically flexible (e.g. grain can be wheat in Europe, while being rice in Asia, and corn in some parts of America). Because the basket is set at the minimum level for subsistence, the level of the real wage or welfare ratio estimated has an intuitive meaning: values above one indicate that wages provide the minimum for subsistence.

Of course, there is not only one such basket, and sometimes price data are not available, which has led different researchers to set up alternative 
versions of them. In the case of Spanish America, for example, we used a comparable basket to Arroyo Abad et al. (2012): the quantities of most nonfood items were identical (though they included 50 per cent more fuel) and food items did not include oil or butter, compensating the caloric intake with more meat and legumes (see Table 1, columns 1 and 3). It is debatable whether one choice is better than other, but both are indeed comparable in the sense that they both provide the same "product» (caloric and protein intake) ${ }^{4}$. Challú and Gomez-Galviarrato (2015) use the same basket we use, yet with different (and more detailed) prices and the results they obtain are comparable to ours ${ }^{5}$.

Using a basket of goods does increase the complexity of the calculations as Dobado has argued, but this does not mean that we should completely abandon this method. In fact, research looking more closely into the assumptions of the welfare ratio methodology generally finds that these are not terribly important. Schneider (2013) showed that changes in mortality and fertility in early modern England had only a small influence on family size and thus the welfare ratio of the average family at the average point in their life cycle. High infant and child mortality and wide spacing of children kept the average number of children being supported by a household at any given time low. Extending this analysis to Latin America, family sizes were likely larger in Spain and Latin America than in England and British North America, amplifying the wage gap. In addition, when studying the diets of the poorest workers in societies around the world, the similarities in diet are much more striking than the differences. Most poor workers in the early modern world survived on a primarily vegetarian diet with smaller amounts of meat, beans and fat. It is true that Argentina may not have fit this general mould, but that does not mean that the other comparisons made are unreasonable or flawed. We agree that when meat is the cheapest source of calories, the baskets should be adjusted accordingly. However, this was not the case in any of the cities we studied.

We also do not deny that some assumptions were required to overcome limited historical evidence and to maintain the comparability of the real wages. A typical example is that of $r_{t}$, which due to lack of data is normally approximated with a fixed percentage of around 5 per cent. This is indeed probably wrong, and recent research has allowed us to know that that number should be pushed upwards for Spain (Drelichman and González Agudo 2014) and perhaps as well for Mexico (Calderón Fernández 2009), but

4 We do not clearly see why Dobado claims that "Arroyo Abad et al. (2012) rightly distinguish between three baskets to capture differences in consumption between Europe and Spanish America» (p. 38, our emphasis), implying we did not, when in fact we do use two different basket (not needing the third, because we did not look at «meat eater» countries in the Spanish colonies).

5 Dobado fails to see this because he is confusing the general with the particular. Within the general Latin American pattern, indeed urban Mexico performs much better than the rest of Latin America and other places in the world (see Allen et al. 2012, figure 5). 
TABLE 1

CONSUMER BASKETS FOR SPANISH AMERICA

\begin{tabular}{|c|c|c|c|c|c|c|c|c|}
\hline & & \multirow[b]{2}{*}{$\begin{array}{l}\text { Allen } e t \text { al. } \\
\left(\mathbf{2 0 1 2}^{1}\right.\end{array}$} & \multicolumn{2}{|c|}{$\begin{array}{c}\text { Arroyo Abad et al. } \\
\text { (2012) }\end{array}$} & \multicolumn{4}{|c|}{ Dobado González and García Montero (2014) } \\
\hline & & & $\begin{array}{c}\text { Meat } \\
\text { eaters }\end{array}$ & Others $^{3}$ & $\underset{\text { (wheat) }}{\text { Grain }}$ & $\begin{array}{l}\text { Grain } \\
\text { (corn) }^{5}\end{array}$ & Meat & Sugar \\
\hline & & (1) & (2) & (3) & (4) & (5) & (6) & (7) \\
\hline Food & & & & & & & & \\
\hline Wheat $(\mathrm{kg})$ & $q^{\mathrm{f} \_ \text {wheat }}$ & 0 & 132 & 0 & 1 & 0 & 0 & 0 \\
\hline Maize $(\mathrm{kg})$ & $q^{\mathrm{f} \_ \text {maize }}$ & 165 & 0 & 165 & 0 & 1 & 0 & 0 \\
\hline Legumes (kg) & $q^{\text {f_legume }}$ & 20 & 0 & 45 & 0 & 0 & 0 & 0 \\
\hline Meat (kg) & $q^{\mathrm{f} \_ \text {meat }}$ & 5 & 105 & 35 & 0 & 0 & 1 & 0 \\
\hline Butter (kg) & $q^{\mathrm{f} \_ \text {butter }}$ & 3 & 0 & 0 & 0 & 0 & 0 & 0 \\
\hline Sugar $(\mathrm{kg})$ & $q^{\mathrm{f} \_ \text {sugar }}$ & 0 & 0 & 0 & 0 & 0 & 0 & 1 \\
\hline Calories & & 1963 & 1938 & 1943 & $\begin{array}{c}\text { Not } \\
\text { defined }\end{array}$ & $\begin{array}{c}\text { Not } \\
\text { defined }\end{array}$ & $\begin{array}{c}\text { Not } \\
\text { defined }\end{array}$ & $\begin{array}{c}\text { Not } \\
\text { defined }\end{array}$ \\
\hline Non-food & & & & & & & & \\
\hline Soap (kg) & $q^{\text {nf_soap }}$ & 1.3 & 1.3 & 1.3 & 0 & 0 & 0 & 0 \\
\hline Cloth (m) & $q^{\text {nf_cloth }}$ & 3 & 3 & 3 & 0 & 0 & 0 & 0 \\
\hline Candles (kg) & $q^{\text {nf_light }}$ & 1.3 & 1.3 & 1.3 & 0 & 0 & 0 & 0 \\
\hline Lamp oil (l) & $q^{\text {nf_oil }}$ & 1.3 & 1.3 & 1.3 & 0 & 0 & 0 & 0 \\
\hline Fuel (M. BTU) & $q^{\text {nf_fuel }}$ & 2.0 & 3.0 & 3.0 & 0 & 0 & 0 & 0 \\
\hline
\end{tabular}

Notes:

${ }^{1}$ Bogota, Mexico and Potosi.

${ }^{2}$ Argentina and Chile.

${ }^{3}$ Bolivia, Colombia, Mexico, Peru.

${ }^{4}$ Buenos Aires

${ }^{5}$ Bogota, Guadalajara, Mexico, Potosi. 
until those uncertainties are resolved, we think being explicit about a reasonable lower bound makes more sense than ignoring the issue altogether (as the Dobado-García approach does). We tried to be very clear about the interpolations that we made to deal with shortfalls in historical evidence in our 30-page data appendix to the final published paper. All of our assumptions are clearly laid out for scrutiny and further analysis. We also acknowledge that household consumption has changed over time as relative prices have shifted and new products have been introduced, but allowing each individual basket to change over time makes it much more difficult to create comparable price baskets across countries ${ }^{6}$. We do not deny that new commodities like sugar were important for workers' lives, but the new commodities are less relevant when creating a subsistence basket of goods representing the cheapest way to reach a survival level of calories and proteins.

\section{LIMITATIONS OF USING SINGLE PRODUCT RATIOS}

In the face of the strength and analytical clarity of the welfare ratio methodology, Dobado and García's method of comparing commodity wages is interpretively unsatisfying and does not fit economic historian's understanding of economic development in the past. Dobado's table 5 shows that the ordinal ranking of commodity wages varies dramatically across the four commodities measured (Dobado-González 2015). This is not surprising given how sensitive the welfare ratio (1) is to changes in the vector $\mathbf{q}_{t}$ and that the implicit choice in the Dobado-García approach is so extreme (see last four columns of our Table 1). Thus, Dobado is essentially arguing that because the relative cost of various goods was different around the world, all countries had the same relative living standards. This is not historically relevant because there are many reasons that a particular city might get a cheap price for a certain commodity that would be unrelated to the overall cost of living. For instance, Potosi had very high silver wages because it had one of the largest silver mines in the world in the colonial period. However, the cost of other goods was also quite high in Potosi bringing the overall welfare ratio down. In addition, meat might have been very cheap in Buenos Aires, but other goods were much more expensive (e.g. legumes). This method also gives us no way of creating a meaningful ranking among countries of how

6 This is not to say that the exercise is not possible. In fact, we know of an unpublished manuscript, presented in the same session were Dobado presented the preliminary results of his paper with García in the CLADHE in Mexico, by Carlos E. Valencia Villa (2010) that attempts to do exactly this by making the basket endogenous to the evolution of prices. This procedure is, however, more demanding on data than the welfare ratio approach, involves performing computationally taxing dynamic programing exercise and is, of course, not assumption-free, as the cross-elasticities of substitutions between items have to be defined somehow. 
much wealthier people in one city were relative to another. For instance, Amsterdam's sugar wages were approximately the same as Calcutta's, but its silver wage was over eight times higher. Were people in Amsterdam better off or worse off than people in Calcutta? Dobado and García's method cannot answer this question. Thus, the fact that certain cities in Latin America end up ahead of some European cities for certain commodities does not provide economically meaningful information.

In addition, Dobado and García's method does not actually overcome the assumptions in our work that they seem to criticise. By comparing the amount of grain that could be purchased by a male day wage, they implicitly assume that men in all countries worked the same number of days and that their family sizes were equal ${ }^{7}$. Otherwise their comparisons are meaningless as a proxy for living standards. They indirectly assume that the value of meat and grain is measured by the kilogram when meat from different animals, different cuts of meat and different types of grain have very different caloric values. Clearly, their methodology is not assumption free either.

Given the strengths of the welfare ratio methodology, which has become widely accepted internationally by economic historians, and the weaknesses of Dobado and García's commodity wage comparisons, we feel Dobado's reflections do not really affect the crucial results we obtained in our paper that there was a substantial gap between British North American and Spanish American real wages in the colonial period. The divergence in the Americas was the product of forces at play from the early colonial era and cannot solely be explained by a reversal of fortune in the late eighteenth and early nineteenth centuries. Thus, the real puzzle is why did this gap exist. The explanation we put forward in our paper suggests that trade and migration patterns created two separate, integrated labour markets across the Atlantic and along with the Malthusian population dynamics of indigenous Americans maintained the wage gap between British North America and Latin America.

\section{REFERENCES}

Acemoglu, D.; Johnson, S., and Robinson, J. (2001): «The Colonial Origins of Comparative Development: An Empirical Investigation». American Economic Review 91 (5), pp. 1369-1401.

Acemoglu, D.; Johnson, S., and Robinson, J. (2002): «The Reversal of Fortune: Geography and Institutions in the Making of the Modern World Income Distribution». Quarterly Journal of Economics 117, pp. 1231-1294.

7 In fact, not being explicit about the assumptions they are making lead Dobado and García to certain estimates that are somewhat difficult to square with the historical debate. For example, it is interesting to note that they implicitly assume that workers spent 312 (!) days working when estimating wages in Chile, as they take the monthly salary of «apiris» (unskilled miner) to correspond to 26 days of work (Dobado González and García Montero 2012, p. 40). 
Acemoglu, D.; Johnson, S., and Robinson, J. (2005): «The Rise of Europe: Atlantic Trade, Institutional Change, and Economic Growth». American Economic Review 95 (3), pp. 546-579.

Allen, R. C. (2001): «The Great Divergence in European Wages and Prices from the Middle Ages to the First World War». Explorations in Economic History 38 (4), pp. 411-447.

Allen, R. C. (2009): The British Industrial Revolution in Global Perspective. Cambridge: Cambridge University Press.

Allen, R. C. (2013): «Poverty Lines in History, Theory, and Current International Practice». Oxford University Department of Economics Discussion Papers No. 685.

Allen, R. C.; Bassino, J.-P.; Ma, D.; Moll-Murata, C., and Van Zanden, J. L. (2011a): Wages, Prices, and Living Standards in China, 1738-1925: In Comparison with Europe, Japan, and India». Economic History Review 64 (1), pp. 8-38.

Allen, R. C.; Murphy, T. E., and Schneider, E. B. (2011b): «The Colonial Origins of the Divergence in the Americas: A Labour Market Approach». IGIER-Università Bocconi, Working Papers Series no 402.

Allen, R. C.; Murphy, T. E., and Schneider, E. B. (2012): «The Colonial Origins of the Divergence in the Americas: A Labor Market Approach». The Journal of Economic History 72 (4), pp. 863-894.

Arroyo Abad, L.; Davies, E., and Van Zanden, J. L. (2012): «Between Conquest and Independence: Real Wages and Demographic Change in Spanish America, 1530-1820». Explorations in Economic History 49 (2), pp. 149-166.

Bairoch, P. (1988): Cities and Economic Development: From the Dawn of History to the Present. Chicago: University of Chicago Press.

Broadberry, S. N. (1997): «The Long Run Growth and Productivity Performance of the United Kingdom». Scottish Journal of Political Economy 44 (4), pp. 403-424.

Broadberry, S. N., and Gupta, B. (2006): «The Early Modern Great Divergence: Wages, Prices and Economic Development in Europe and Asia, 1500-1800». Economic History Review 59, pp. 2-31.

CALderón FernándeZ, A. (2009): «Una serie de precios de vivienda: Las Accesorias del Real Colegio de San Ignacio de Loyola de los Señores Vizcaínos, 1771-1821». $M I M E O$, Paper presented at the II Congreso Latinoamericano de Historia Económica, CLADHE, México DF, Mexico.

Clark, G. (2008): A Farewell to Alms: A Brief Economic History of the World. Princeton: Princeton University Press.

Challú, A. E., and Gomez-Galviarrato, A. (2015): «Mexico's Real Wages in the Age of the Great Divergence, 1750s-1920s». Revista de Historia Económica/Journal of Iberian and Latin American Economic History 33 (1), pp. 83-122.

Deaton, A. (2006): «Measuring Poverty», in A. Banerjee, R. Benabou, and D. Mookerjee (eds) Understanding Poverty. Chapter 2 Oxford: Oxford University Press.

Diamond, J. (1998): Guns, Germs and Steel. London: Vintage.

Dobado-GonzÁlez, R. (2015): «Pre-Independence Spanish Americans: Poor, Short and Unequal... or the Opposite?». Revista de Historia Económica/Journal of Iberian and Latin American Economic History 33 (1), pp. 15-59

Dobado González, R., and García Montero, H. (2009): «Neither So Low Nor So Short! Wages and Heights in Eighteenth and Early Nineteenth Centuries Colonial Hispanic America». WP14/09, Instituto Complutense de Estudios Internacionales, Universidad Complutense de Madrid.

Dobado González, R., and García Montero, H. (2010): «Colonial Origins of Inequality in Hispanic America? Some Reflections based on New Empirical Evidence». Revista de 
Historia Económica/Journal of Iberian and Latin American Economic History 28 (2), pp. 253-277.

Dobado González, R., and García Montero, H. (2012): «Neither So Low Nor So Short: Wages and Heights in Bourbon Spanish America from an International Comparative Perspective». EHES Working Papers in Economic History, No. 14.

Dobado González, R., and García Montero, H. (2014): «Neither So Low Nor So Short: Wages and Heights in Bourbon Spanish America from an International Comparative Perspective». Journal of Latin American Studies 46, pp. 1-31.

Drelichman, M., and Gonzalez Agudo, D. (2014): «Housing and the Cost of Living in Early Modern Toledo». Explorations in Economic History 54, pp. 27-47.

Edwards, S.; Esquivel, G., and Marquez, G. (eds) (2007): The Decline of Latin American Economies: Growth, Institutions, and Crises. Chicago: University of Chicago Press.

Elliot, J. H. (1963): Imperial Spain, 1469-1716. London: E. Arnold.

Engerman, S. L., and SoKoloff, K. L. (1997): «Factor Endowments, Institutions, and Differential Paths of Growth among New World Economies: A View from Economic Historians of the United States», in S. Harber (ed.), How Latin America Fell Behind: Essays on the Economic History of Brazil and Mexico, 1800-1914. Stanford: Stanford University Press, pp. 260-304.

Engerman, S. L., and Sokoloff, K. L. (2002): Factor Endowments, Inequality, and Paths of Development among New World Economics. NBER Working Paper no. w9259.

Hamilton, E. J. (1944): «Use and Misuse of Price History». Journal of Economic History 4 (Supplement: The Tasks of Economic History), pp. 47-60.

Hartwell, R. M. (1967): The Causes of the Industrial Revolution. London: Methuen \& Co..

Jones, E. (1981): The European Miracle: Environments, Economies and Geopolitics in the History of Europe and Asia. Cambridge: Cambridge University Press.

Landes, D. (1998): The Wealth and Poverty of Nations. London: Little, Brown and Company.

North, D. C., and Thomas, R. P. (1973): The Rise of the Western World. Cambridge: Cambridge University Press.

PamuK, S. (2007): "The Black Death and the origins of the 'Great Divergence' across Europe, 1300-1600». European Review of Economic History 11, pp. 289-317.

Parthasarathi, P. (2011): Why Europe Grew Rich and Asia Did Not? Cambridge: Cambridge University Press.

Phelps-Brown, H., and Hopkins, S. V. (1981): A Perspective of Wages and Prices. London: Methecen.

Pomeranz, K. (2000): The Great Divergence: China, Europe, and the Making of the Modern World Economy. Princeton: Princeton University Press.

Prados De La Escosura, L. (2007): "When did Latin America Fall Behind?», in S. Edwards, G. Esquivel and G. Marquez (eds), The Decline of Latin American Economies: Growth, Institutions, and Crises. Chicago, IL: University of Chicago Press, pp. 15-57.

Salvatore, R. D.; Coatsworth, J. H., and Challú, A. E. (eds) (2010): Living Standards in Latin American History: Height, Welfare, and Development, 1750-2000. Cambridge, MA: Harvard University Press and the David Rockefeller Center for Latin American Studies.

SchneIDER, E. B. (2013): «Real Wages and the Family: Adjusting Real Wages to Changing Demography in Pre-Modern England». Explorations in Economic History 50 (1), pp. 99-115. 
Valencia Villa, C. E. (2010): «Costos de los alimentos y renta de los trabajadores libres en Río de Janeiro (Brasil) y Richmond (Virginia, EUA) en la primera mitad del siglo XIX». MIMEO, Paper presented at the II Congreso Latinoamericano de Historia Económica, CLADHE, México DF, Mexico.

VAN ZANDEN, J. L. (1999): «Wages and the Standard of Living in Europe, 1500-1800». European Review of Economic History 3, pp. 175-197.

Van Zanden, J. L. (2009): The Long Road to the Industrial Revolution: The European Economy in Global Perspective, 1000-1800. Leiden: Brill. 